\title{
PERLUNYA PENGEMBANGAN SISTEM INFORMASI DALAM PENDIDIKAN
}

\author{
SONIA MELSA
}

\author{
Email: Soniamelsa72@gmail.com
}

\begin{abstract}
Abstrak
Artikel ini bertujuan untuk mengetahui perlunya pengembangan system informasi dalam pendidikan serta implementasi sistem informasi dalam pendidikan. Hal ini berkaitan dengan kemajuan teknologi dalam pendidikan dan menciptakan mutu pendidikan yang berkualitas. Pengembangan sistem informasi dapat mempermudah jalannya sistem informasi manajemen di sekolah dan dapat mengembangkan bagian sistem yang sudah tertinggal agar lebih canggih lagi sesuai perkembangan zaman.
\end{abstract}

Keyword: perlunya pengembangan, sistem informasi manajemen, lembaga pendidikan

\section{LATAR BELAKANG}

Perlunya pengembangansistem informasi manajemen digunakan untuk mengontro alur informasi dalam setiap proses secara cepat dan akurat. Pada era teknologi seperti saat ini, informasi memegang peranan yang sangat penting dalam lembaga pendidikan, dengan adanya sistem informasi yang efisien dan efektif dalam proses sistem manajemen pendidikan yang berlangsung akan mempermudah pihak-pihak yang terkait untuk mempermidah membuat keputusan secara tepat dan tepat serta dapat meningkatkan kinerja agar bisa menciptakan suatu lembaga pendidikan yang bermutu.

Menurut sabandi Siatem Informasi Manajemen (SIM) adalah suatu metode untuk menghasilkan informasi yang tepat waktu bagi, manajemen tentang lingkungan luar organisasi, dengan tujuan untuk menunjang proses pengambilan keputusan serta memperbaiki proses perencanaan dan pengwasan. Dengan adanya sistem informasi manajemen sangat membantu dan mempermudah kinerja guru dalam meningkatkan mutu pendidikan di Indonesia. (Sabandi, 2019) 


\section{PEMBAHASAN}

\section{Pengertian Sistem Informasi Manajemen}

Menurut Mc.Leod dalam Yakub (2012) SIM didefinisikan sebagai suatu sistem berbasis computer yang menyediakan informasi bagi beberapa pemakai dengan kebutuhan serupa. (YAKUB, 2012)

Menurut Sabandi dan Vindi "Sistem Informasi Manajemen adalah sebuah metode yang digunakan oleh pemakai informasi untuk mengelola data, baik itu data siswa maupun data guru yang akan menjadi bahan pertimbangan dalam sebuah proses pengambilan keputusan. (Sabandi, 2019)

Jadi, sistem informasi manajemen adalah sebuah sistem yang berbasis computer yang digunakan oleh pemakai informasi untuk mengelola data dan menjadi bahan pertimbangan untuk mengambil keputusan.

\section{Tujuan Sistem Informasi Manajemen}

Tujuan sistem informasi manajemen dapat terbagi beberapa tujuan sebagai berikut:

1. Menyediakan informasi yang dipergunakan di dalam pengambilan suatu keputusan.

2. Untuk menyediakan suatu informasi yang digunakan didalam suatu perencanaan, pengendalian, pengevaluasian dan juga perbaikan berkelanjutan.

3. Untuk menyediakan suatu informasi yang dipergunakan di dalam suatu perhitungan harga pokok produk, jasa dan tujuan lainnnya yang diinginkan oleh manajemen.

4. Menyediakan akses informasi yang cepat dan tepat terkait dunia pendidikan yang berguna bagi pendidik dan peserta didik.

\section{Manfaat Sistem Informasi Manajemen}

1. Dapat menghasilkan suatu sistem yang berguna

2. Menjadikan suatu informasi yang lebih bermanfaat bagi lembaga pendidikan

3. Mempermudah mengetahui informasi yang akan dibutuhkan

4. Informasi lebih akurat

5. Mempertmudah mengolah transaksi- transaksi

6. Membuat keputusan yang lebih terarah

7. Dapat mengurangi suatu ketidakpastian pada system

8. Sebagai antisipasi dan memahami konsekuensi ekonomi dari sebuah sistem dan teknologi baru 
9. Mempermudah pekerjaan bagi pendidik dala, mengelola informasi dan mendapatkan informasi yang akurat.

\section{Implementasi Sistem Informasi Manajemen dalam Manajemen Sekolah}

Sistem informasi manajemen sekolah dapat dikatakan berjalan apabila semua komponen sekolah dapat menggunakan dan memafaatkan sistem itu sendiri. Pada pelaksanaan iimplementasi sistem informasi manajemen sekolah,, suatu sistem dapat dikatakan bberjalan baik dan normal apabila seluruh komponen sekolah bisa menggunakan dan memanfaatkan fasilitas sesuai dengan kebutuhan masing-masing dan tidak tergantung pada administrator sekolah.

Manajemen pendidikan merupakan sekumpulan fungsi menjamin efisiensi dan efektiivitas pelayanan pendidikan, melalui perencanaan, pengambilan keputusan, perilaku kepemimpinan, penyiapan alokasi sumber daya, stimulus dan koordinasi personil, penciptaan iklim organisasi yang kondusif, serta penentuan pengembangan fasilitas untuk memenuhi kebutuhan siswa dam masyarakat di masa depan. Sehingga dapat dikatakan bahwa manajemen pendidikan pada hakikatnya adalah menyangkut tujuan pendidikan, manusia yang melakukan kerjasama, proses sistematik serta sumber-sumber yang didayagunakan.

Untuk melihat sampai sejauh mana prosoes implementasi pengolaan sistem informasi manajemen pendidikan, sebagai kepala sekolah mempunyai beberapa kriteria dalam menjalankan sistem informasi manajemen pendidikan antara lain sebagai berikut:

a. Dapat menentukan pendekatan yang tepat dalam merencanakan sistem informasi manajemen pendidikan di sekolahnya.

b. Penerapan sistem informasi manajemen pendidikan secara efektif dan efisien oleh kepala sekolah ditunjukkan dengan kemampuan: mengumpilkan data secara komprehensif sesuai dengan kebutuhan, mampu mengolah data menjadi informasi yang tepat, mampu menggunakan sistem informasi manajemen pendidikan sebagai hasil plahan dalam mengambil keputusan.

\section{Perlunya Pengembangan Sistem Informasi Manajemen dalam Pendidikan}

(YAKUB, 2012) Menurut Jogiyanto, 1999 dalam buku Yakub pengembangan sistem berarti menyusun suatu sistem yang baru untuk menggantikan sistem yang lama secara keseluruhan atau memperbaiki atau diganti disebabkan beberapa hal sebagai berikut: 
a. Adanya permasalahan-permasalahan yang timbul di sistem yang lama. Permasalaham yang timbul dapat berupaa, ketidakberesan dan pertumbuhan organisasi.

b. Untuk meraih kesempatan-kesempatan. Kesempatan-kesempatan dapat berupa peluang-peluang pasar, pelayanan yang meningkat kepada pelanggan dan sebagainya.

c. Adanya instruksi-instruksi. Penyusunan sistem baru dapat juga terjadi karena adanya instruksi-instruksi dari pimpinan atau luar organisasi, seperti peraturan pemerintah.

Karena adanya permasalahan, kesempatan, dan instruksi, maka sistem yang baru perlu dikembangkan untuk memecahkan permasalahan-permasalahan yang timbul, meraih kesempatan-kesempatan yang ada, dan memenuhi instruksi yang diberikan. Maka dari itu perlu di adakan pengembangan sistem informasi manajemen dalam pendidikan.

Perlunya pengembangan sistem informasi digunakan untuk mengontrol alur informasi dalam setiap proses secara cepat dan akurat. Pada era teknologi seperti sekarang ini, iinformasi memegang peranan yang sangat penting dalam operasional suatu pendidikan. Dengan adanya sistem informasi yang telah di kembangkan akan mempermudah pihak-pihak yang terkait untuk dapat membuat keputusan secara cepat dan tepat.

\section{PENUTUP}

Pengembangan sistem berarti menyusun suatu sistem yang baru untuk menggantikan sistem yang lama secara keseluruhan atau memperbaiki atau diganti disebabkan beberapa hal

Perlunya pengembangan sistem informasi digunakan untuk mengontrol alur informasi dalam setiap proses secara cepat dan akurat. Pada era teknologi seperti sekarang ini, iinformasi memegang peranan yang sangat penting dalam operasional suatu pendidikan.

\section{DAFTAR PUSTAKA}

Sabandi, A. (2019). PERSEPSI GURU TERHADAP PENERAPAN SISTEM INFORMASI MANAJEMEN AKADEMIK DI SEKOLAH MENENGAH KEJURUAN (SMK) NEGERI 3 PADANG. Bahana Manajemen Pendidikan, 8 NOMOR 1, 8. Retrieved from file:///C:/Users/ASUS/Documents/sabandi10370429550-1-PB (1).pdf 
YAKUB. (2012). PENGANTAR SISTEM INFORMASI (PERTAMA). YOGYAKARTA: 2012. 